\title{
Development of a Scientific Literate Society: Status and Challenges
}

\author{
Lilia Halim \\ Faculty of Education, Universiti Kebangsaan Malaysia, Selangor, 43650, Malaysia \\ lilia@ukm.edu.my
}

\begin{abstract}
Building a scientific society is a necessary prerequisite for Malaysia in its attempt to be a developed and modern society based on science and technology. A scientifically literate society entails citizens who are literate in science and technology, and are able to make rational and objective decisions based on such knowledge for the society well-being. Besides being a consumer of scientific developments and innovations, a scientifically literate society requires a critical social mass that will ensure the availability of human capital for innovation and progress based on science and technology. The main vehicle to realise this agenda is through science education. This paper, based on the work undertaken by the author in the field of science education in Malaysia and related works of other scholars pertaining to scientific literacy, offers reflections on the following four questions: the importance of developing a scientific literate society; the level of scientific literacy achieved, the factors contributing to the level of scientific literacy, and the challenges in developing a scientifically literate society. The paper argues that while the level of scientific literacy in Malaysia is commendable, there is still a lot of room for improvement. To achieve this, two central issues need to be addressed: the quality of science teachers and their professionalism.
\end{abstract}

Index Term - Scientific Literacy, Human Capacity Building, Science Education

\section{Introduction}

A huge part of our lives in this globalized era is influenced by the development of science and technology. The development of science and technology has brought positive impact on social development. For instance, the food we produce and consume are befitting through food technology that was not present in the earlier days. At the same time, the impact of science and technology does not often lead to positive impact. The water pollution and global warming phenomena are outcomes of scientific and technological advancement that is mismanaged.

Therefore, for a livable condition in this post- industrial era, it would depend on our ability to understand and apply the products of science and technology advancement in a responsible manner. As a responsible user of the outcomes of scientific and technological advancement, we need to consider the ethics and values associated with the impact of the advancement. In realizing that, one needs a scientific literate society so that the societal development is sustainable. The sustainable development of a country can be achieved when the society has the culture of being literate in science and technology (S\&T) and are smart consumers of the outcomes of S\&T.

The focus of this paper is on how to develop the scientific literate individuals; who are aware and also able to use the S \& T knowledge and its applications and aware of the positive or negative impacts. Based on research in science education with my peers and graduate students, I would like to offers reflections on the following four questions: the importance of developing a scientific literate society; the level of scientific literacy achieved, the factors contributing to the level of scientific literacy, and the challenges faced in developing a scientifically literate society.

\section{Why the need of a scientific literate society?}

The need is seen from four perspectives. First is the Utilitarian perspective, where science and technology is important for those who are interested in pursuing a career in science and technology and for individuals to function effectively in the current economic world that is heavily dependent on science and technology. Second is the democratic perspective, a basis to increase the involvement of the society in socio-scientific consciousness and develop civic consciousness among the society towards those issues encountered in everyday situation. A recent situation in Malaysia was the issue of development of a nuclear plant in Kuantan. Third- is the economic perspective - this perspective appears to be the driving force for a developing nation such as Malaysia to develop a scientific literate society so that the country is able to compete at the global level. Fourth - the cultural perspective- that views scientific knowledge as a body of knowledge that needs to be inherited understood and acquired, which in turn signifies that the nation attains the highest level of civilization.

Based on the four perspectives, it is imperative that a developing nation such as Malaysia, should have the individuals in the society to be scientific literate that is not only to be aware of science but to be smart in science. Smart here means to be able to draw on the body of scientific knowledge, the processes and values associated with it in making an informed decision when dealing $\mathrm{S} \& \mathrm{~T}$ issues related to personal life, environment, community, work place and country as a whole.

\section{What are the characteristics of a scientific literate individual?}

Basically, the individual has the following combination of characteristics:

a. to be able to acquire scientific knowledge and able to interpret a phenomena scientifically,

b. to adopt and practice the inquiry - in developing scientific knowledge it has to be based on scientific evidence and not based on myth and superstitious knowledge, 
c. to be able to make informed decision based on scientific evidence- involving critical thinking and ability to evaluate arguments and scientific evidence, and

d) to understand the development of science and technology is a human activity influenced by the cultural perspectives, ethics and moral in solving socio-scientific problems. In short, a scientific literate individual is able to a) distinguish scientific knowledge from a popular myth, b) differentiate evidence from propaganda and c) separate facts from fabricated data.

\section{How to develop a scientific literate society?}

In Malaysia, various systemic efforts have been put in place to develop and enhance the level of scientific literacy in the society since 50 years ago. Among the initiatives are: through policies related to $\mathrm{S} \& \mathrm{~T}$ development in the various Malaysian Economic plan and the policy to ensure 60:40 ratio of science to arts students in schools. Because of these policies, science education has always been given priority in the school curriculum from primary to secondary level. Science is a compulsory subject to all. The agenda of developing a scientific literate society has been implemented in the formal science curriculum and it is done in stages.

\section{What is the status?}

The question now is to what extent science education has been successful in creating learning experiences aimed at creating scientific literate students? To what extent, science teachers, as implementation agents in developing science literacy are able to provide such learning experiences. I would like to share findings from studies conducted either by myself or the literature in promoting the development of scientific literate society with the aim of evaluating the efforts in creating scientific literate characteristics among students and teachers.

A. My early years of research were to explore on the acquisition of conceptual understanding among primary and secondary teachers and students including university students studying Physics, Chemistry and Biology. Research findings showed that the conceptual understanding of the respondents was not aligned to the scientific explanations, whereby misconceptions still exist among them; despite the fact that students and teachers had gone through for at least 12 years of science learning [1][2]. This phenomenon is not unique to Malaysia because misconceptions also exist among students in other developing and developed countries. In recent years, the ability of Malaysian students compared students of other nations, in the cognitive domain (knowledge, application and reasoning) is below the TIMSS minimum score. For the knowledge acquisition component, majority of the Malaysian students achieve the average benchmark score $(n=457)$. While only 3 percent of Malaysia students are able to demonstrate deep conceptual understanding of certain complex and abstract concepts.

Various factors contribute to the development of misconceptions and in turns affect the acquisition of the concepts. Teachers indirectly contribute to the misconceptions held by students. For example in a recent study, on kinetic theory, only two out of 10 science teachers were able to provide the correct understanding of the concept [3]. The irony is that this question is often taught at school and tested in public examination.

B. Competency related to explaining everyday situation scientifically is also being examined at international levelnamely PISA. Malaysia's performance was ranked 52 out of 74 participating countries. This competency was investigated among science teacher trainees and they appear to encounter difficulties in explaining everyday phenomena scientifically [4]. It was found that half of the respondents including those majoring in Physics did not provide answers that are aligned with the scientific explanation. Such findings indicate that students including adults who received 15 years of science education are more incline to explain everyday phenomena using logical answers as compared to providing scientific explanation.

'Bicyele Grips"

Lis the mernin:, Sally noticed the metal part or the handle bars of bicycle folt colder than the plastic grips.

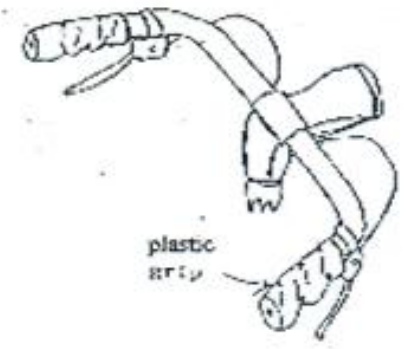

What is the reason for this ?

Plesse explain your answer as cleiuly as possible?

Fig. 1 Question sets in an everyday context

C. Ability to apply scientific knowledge effectively and meaningfully requires deep reasoning. Research on high ability students solving non routine problems indicate that these students give less focus in identifying concepts involved in solving the problems and they tend not to focus on planning for solving the problem [5]. Instead, these students are eager to solve the problems after extracting relevant information from the problem. Surface level reasoning, as such, is as a result of them being over exposed to drill and practice in preparation for meeting the high stake national examination.

D. The inculcation and acquisition inquiry method is the main characteristic in the science discipline. Often, the inquiry method is formed through laboratory activities that are supported by the science process skills. In fact, students like science because this is the subject matter that involves laboratory activities. However, if lab activities are conducted, students are not given the opportunity to explore and construct their understanding by themselves of the 
phenomena that they are investigating. This is because most of the lab activities are in the form of 'cook book' in which the lab activities are conducted by following steps with the aim to endorse known answers.

On the other hand, Refs. [6] and [7] have shown that students yearn for laboratory activities that allow them to create ideas and not laboratory activities that lead to confirm the theory like what is currently being practiced now. Even though students like laboratory activities (OE) for which it helps them to understand science, teachers seldom conduct such activities. Among the factors is time constrain whereby teachers aim to cover the syllabus in preparation for the national examination.

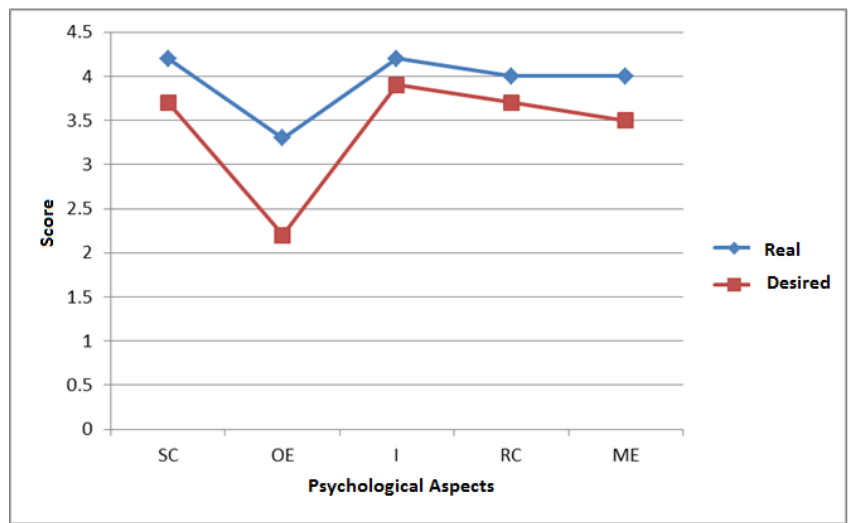

Fig. 2 Comparison between students' perceptions on the laboratory environment current and intended.

Legend translation:

Skor-score

Sebenar- Actual

Diingini- Expectation

Aspek-aspek psikologikal- Psychological aspects

The overemphasis on the national examination achievement appears to be the main contributing factor to the teaching approach that is mainly didactic and less inquiry based. Other contributing factors are the lack of lab apparatus and rooms. Teachers who hold the conception that science activities and the nature of science as an activity to confirm scientific theories reinforces teaching approach that is not inquiry based.

Such a teaching and learning approach indirectly contributes to the lack of acquisition of science process skills among the students. It was found that students lack the skills of making generalizations and constructing hypothesis. Both skills are complex and integrated. These skills are compared between Malaysian and Japanese students [8]. Findings showed that Japanese students level of science process skills are higher than Malaysian students, even though it was found that Malaysian students have higher level of interest in science compared to the Japanese.

Proficiency of science process skills of students to some extent is influenced by teachers' competencies as well. It was found that teachers are able to acquire process skills in the operational manner but not conceptually. When teachers' understanding is low, they will face difficulty in teaching the skills and most probably will not teach the skills [9].

E. Work has been done in exploring alternative ways to increase inquiry skills. I found that the physical form of laboratory does contribute to the development of scientific literacy.

A laboratory model that integrates elements of theory and practical work is presented; this model allows theory development followed by confirming the theory and finally looking back to the process of theory development. This dynamic activity reflects the actual work of a scientist which cannot be done in the current physical form of science and physics laboratories in most schools.

For schools without sophisticated labs, the learning and teaching approach that is hands on and uses the environment as well as low cost material is also able to facilitate students to acquire the inquiry skills. This alternative approach takes into account the needs and abilities of rural and marginalized students, hence giving equal opportunities in science learning.

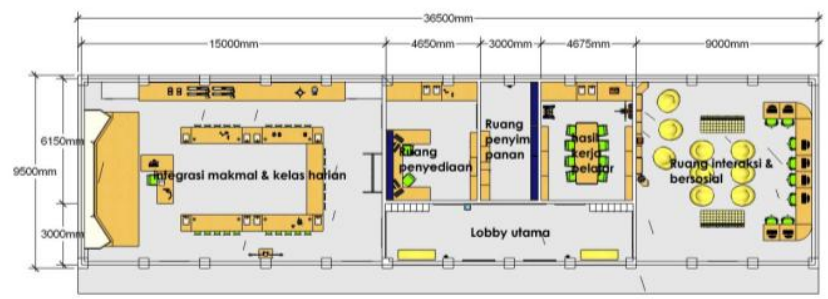

Fig. 3 Design Features of Science Laboratories integrating theoretical discussion and practical work

Label translations:

Integrasi makmal \& kelas harian- Integration laboratory with everyday classroom

Ruang penyediaan- Preparation area

Ruang penyimpanan- Storage area

Bilik kerja pelajar- Students working room

Ruang interaksi dan bersosial- Interaction and socialization area

Inquiry skills can also be inculcated through project or research based science activities. A model of science teaching and learning integrating the discipline of science and entrepreneurship has been proposed. This model is able to develop both the science process skills as well as creative and innovative thinking.

The underlying concept of this model is based on the thinking and process of entrepreneurial scientists in developing creative and innovative product.[10] The creation of the products is based on science concepts. The application of science in creation or technological innovation is done during the Renaissance era among the developed countries. This interdisciplinary concept of science learning is currently gaining recognition and it is widely known as Science, Technology, Engineering and Mathematics (STEM)

F. Scientific attitude is another characteristic of scientific literate individual, which also reflects the behavior of a scientist. This attitude and habit of thinking, which always asks questions and makes decisions based on data, is necessary in evaluating socio-science dilemmas related to political, moral and economy realm.

Unconsciously or consciously, we are forced to make the evaluation. For example, is it true that the H1N1 virus could be transferred from human to human? Or is true that Rafflesia is used in traditional medicine (jamu) and is able to reduce weight? For someone who is science literate, one 
is able to appreciate that scientific knowledge is not absolute and not free from the political or economic influence.

With scientific attitude also encourages the society members to find out the reasons why an event happens such as 'Why Tsunami happened? And is there any scientific explanation behind the event? These questions are not only important for policy makers but also important for society members so that one can make informed decision and its impact on the wellbeing of the individual, economy and environment.

Research [11] has shown that the scientific attitude among teachers and students is low. Teachers' attitude is lower compared to the students. It can be inferred that the learning environment provided does not encourage the development of scientific attitude and its practices. Again the pressure of having to complete the syllabus in preparing for national examination has impacted on the teaching and learning approach which is didactic in nature.

TABLE 1 Trends of scientific attitude among teachers and students.

\begin{tabular}{|c|c|c|}
\hline $\begin{array}{c}\text { Characteristics of scientific } \\
\text { attitude }\end{array}$ & $\begin{array}{c}\text { Teacher } \\
(\mathrm{n}=109) \\
\%\end{array}$ & $\begin{array}{c}\text { Student } \\
(\mathrm{n}=493) \\
\%\end{array}$ \\
\hline $\begin{array}{l}\text { Critical Thinking } \\
\text { (habit of asking) }\end{array}$ & 15 & 40.2 \\
\hline $\begin{array}{l}\text { Hold judgment } \\
\text { (always collect data/ refer to } \\
\text { experts) }\end{array}$ & 28 & 34.1 \\
\hline $\begin{array}{c}\text { Based on evidence } \\
\text { (depends on facts and } \\
\text { empirical data to make } \\
\text { decision and solve problem) }\end{array}$ & 32 & 49.1 \\
\hline $\begin{array}{c}\text { Honesty } \\
\text { (conduct preliminary } \\
\text { observation even though } \\
\text { observation rejects initial } \\
\text { hypothesis) }\end{array}$ & 29 & 42.2 \\
\hline $\begin{array}{c}\text { Objectivity } \\
\text { (objective attitude) }\end{array}$ & 35 & 26.4 \\
\hline $\begin{array}{l}\text { Open mindedness } \\
\text { (able to accept concepts that } \\
\text { are tentative, thus the } \\
\text { knowledge is dynamic) }\end{array}$ & 28 & 39.9 \\
\hline
\end{tabular}

\section{Challenges in developing a scientific literate society}

Two challenges were determined based on the previous studies. The first challenge is to ensure that all students are scientific literate. The science education needs to enhance its role in developing students who are literate and smart in science, by giving emphasis to develop each characteristic of a literate society discussed earlier. This should be done in a holistic manner through the curriculum, teaching and learning process, evaluation and teaching and learning materials. Indeed, there is a need to ensure alignment between those educational elements.

What has happened is that the science curriculum in Malaysia like in any other countries has gone through the process of 'deconstruct' and 'reconstruct'. This activity does not mean it is not a good thing to do. But as mentioned by reference [12], the changes in the curriculum is similar to the Heisenberg's Uncertainty principle'... that at the macroscopic level there is a fundamental indeterminacy in the Universe- the more accurately you measure the position of an object, the less certain you are of its velocity'.

With reference to the principle in the context of science education, it means that the more we try to determine what needs to be taught and how it should be assessed, we find ourselves to be further away from our target. That is we may be far away from knowing or determining what are the basic things need to be taught and evaluated in science education.

It appears that the conception of science and its nature, which emphasizes on inquiry, even though embrace in the science curriculum and syllabus and its being documented, but the teaching and learning process does not reflect that and not being experienced by students.

This brings to the second challenge mainly to encourage science teachers to change the teaching and learning approach to be more hands on and inquiry based. It is clear that in order for this to happen; the characteristics and pedagogy of the teachers need to be enhanced through the development of quality science teachers.

A trained teacher is a professional that has both pedagogical skills and other professional knowledge related to teaching. One unique type of a professional knowledge is Pedagogical Content Knowledge. This knowledge is the missing paradigm in the training of science teachers.

This professional knowledge of teaching differentiates a scientist from a science educator. A scientist has scientific knowledge while a science teacher needs to translate the scientific knowledge and its nature so that it is comprehensible to the students. This is where the role of the science teachers in developing scientific literate students.

The lack of development of PCK among science teachers has an impact on the quality of science teaching. Teachers are found to be incapable in transforming the content knowledge for the students thus leads to reinforcing misconceptions of the students. Teachers also tend to teach didactically and less on inquiry based activities. Teachers also found to face stress when they teach outside their option when they do not have a good level of PCK. [13]

Therefore, the model of teacher training should be based on the conception of science. The development of PCK is very important in the model and the professional development of the teachers especially among the trainees should be based on action research based training. Being novice, they need to be trained to reflect on and in their actions so that they could plan for an effective and meaningful science teaching and learning. [14]

The professional development of teachers should also have the element of developmental research. Any innovation 
in teaching and learning science based on research should be drawn upon in creating teaching and learning plans and assessment. Thus, making the professional development of teachers becomes research based.

\section{Conclusion}

To conclude, the level of scientific literate and strategies to overcome them can be summarized using the economic metaphor as shown as follows: The rate of development of scientific literate society depends on how fast the teacher understands and teaches science according to the nature of science and the characteristics of scientific literate individuals. In order for this to happen, there must be a change of paradigm on how science teachers are trained and on the nature of their professional development. The development of quality science teachers is the key to the development of a scientific literate society.

\section{Acknowledgment}

I would like to express my sincere appreciation to all the graduate students and colleagues that have worked together in research and teaching for the development of a scientific literate society in Malaysia

\section{References}

[1] L. Halim, "Improving science education in schools from the perspective of teacher training". Journal of Science and Mathematics Education in Southeast Asia, XXI(2): 1998, pp. 19-29.

[2] R. Samad, "Misconceptions in Astronomy among primary school teachers," Unpublished Master Thesis, Faculty of Education, Universiti Kebangsaan Malaysia, 2007,

[3] D. F. Treagust, A. L. Chandrasegara, A. N. M. Zain, Ong, M. Karpudewan, and L. Halim, "Evaluation of an intervention instructional program to facilitate understanding of basic participle concepts among students enrolled in several levels of study," Chemistry Education Research and Practice, vol. 12, no. 2, pp. 251261, 2011.

[4] L. Halim and T. S. Meerah, "Science trainee teachers' Pedagogical Content Knowledge and its influence on physics teaching," Research in Science and Technological Education, vol. 20, no. 2, pp. 215-227, 2002.

[5] M. Syukri, L. Halim, and T. S. Meerah, "Model pendekatan pakar fisika dalam menyelesaikan masalah fisika kontekstual: Sebuah studi kasus, (Expert model approach in solving physics contextual problem: A case study)," Jurnal Pendidikan Fisika Indonesia, vol. 8, no. 1, pp. 61-67, 2012.

[6] C. N. C. Ahmad, K. Osman, and L. Halim, "Physical and psychosocial aspects of science laboratory learning environment," Procedia-Social and Behavioral Sciences, vol. 9, pp. 87-91, 2010.

[7] L. Halim L., S. I. S. Abdullah, and T. S. Meerah, "Students" perception of their Science Teachers' Pedagogical content knowledge," Journal of Science Education and Technology, vol. 23, no. 2, pp. 227-237, 2014.

[8] L. Halim, T. S. Meerah, K. Osman, N. A. Buang, M. A. Samsudin, and M. Sugimura, "The level of scientific culture among Malaysia and Japanese students," Procedia - Social and Behavioral Sciences, vol. 8, pp. 2809-2813, 2009.

[9] E. H. Shahli, L. Halim, and T. S. Meerah, "Perception, conceptual knowledge and competency level of integrated science process skill towards planning a professional enhancement program," Sains Malaysiana, vol. 41, no. 7, pp. 921-930, 2012.

[10] N. A. Buang, L. Halim, and T. S. Meerah, "Understanding the thinking of Malaysian entrepreneurial scientists: Implications for science education in Malaysia," Journal of Turkish Science Education, vol. 6, no. 2, pp. 3-11, 2009.

[11] K. Osman, L. Halim, and Z. Iksan, "The critical thinking attitudinal profile of some Malaysian secondary students: a reflection of scientific attitude," Journal of Science and Mathematics Education in Southeast Asia, vol.26, pp. 143-168, 2003.

[12] J. Osborne, "Science education for the twenty first century," Euroasia Journal of Mathematics, Science \& Technology Education, vol. 3, no. 3, pp. 173-184, 2007.

[13] L. Halim, M. A. Samsudin, T. S. Meerah, and K. Osman, "Measuring science teachers' stress triggered by multiple conditions," International Journal of Science \& Mathematics Education, pp. 727739, 2006.

[14] L. Halim, N. A. Buang, and T. S. Meerah, "Action research as instructional supervision: Impact on the professional development of university based supervisors and science student teachers," ProcediaSocial and Behavioral Sciences, vol. 9, pp. 2868-2871, 2010. 